DOI: 10.52363/2414-5866-2021-1-13

УДК: 342.7.349

Лопушинський І.П., д.держ.упр., проф., ХНТУ, м. Херсон, ORCID: 0000-0002-7460-7476,

Ковнір O.I., к.пед.н., дои., ХМКРП, м. Херсон, ОRCID: 0000-0003-0574-2903

Lopushynskyi I., Doctor of Public Administration, Prof.,

Kherson national technical university, Kherson,

Kovnir O., Ph.D in Pedagogical Sciences, Assoc. Prof., lecturer of Kherson maritime college of fishing industry, Kherson

\title{
МОБІНГ (ЦЬКУВАННЯ)В УПРАВЛІННІ ПЕРСОНАЛОМ: МЕХАНІЗМИ ПРАВОВОГО ВРЕГУЛЮВАННЯ В УКРАЇНІ ТА СВІТІ
}

\section{MOBBING (HARASSMENT) IN PERSONNEL MANAGEMENT: MECHANISMS OF LEGAL SETTLEMENT IN UKRAINE AND THE WORLD}

У статті розглядаються теоретичні засади існування такого вкрай небезпечного соиіального явища, як мобінг (цькування) на роботі (як вертикальний, так $і$ горизонтальний);показано, щзо в украӥнському суспільстві наразі зростає психологічний пресинг на працівників через часом некомпетентних керівників, їхні особисті амбіиії (босинг), брак робочих місиь, прагнення окремими недобросовісними $i$ малокомпетентними працівниками незаслужено посістибільш перспективне й краще оплачуване місце, перманентне зростання безробіття (навіть офіиійного), яке наразі ускладнене ще й епідемією COVID-19; досліджено історію вивчення та описання мобінгу; доведено, щзо, крім вертикального і горизонтального мобінгу, у наших реаліях має місце й інституцііональний мобінг, під яким науковці розуміють моральне переслідування працівників, у тому числі й на публічній службі, з використанням таких інститутів, як конкурси, щзорічна оцінка, атестаџія персоналу, кваліфікаційні іспити, розгляд службових спорів, службові розслідування тощз; висвітлено міжнародне та європейське законодавче забезпечення запобігання та протидіі мобінгу; показано, щзо тенденції українського законотворчого процесу свідчать про те, щзо Українська держава намагається послідовно проводити політику із забезпечення права на повагу до честі й гідності особи; водночасдоведено, щуо у вітчизняному законодавстві питання протидії мобінгу не знайшло свого належного закріплення; проаналізовано перспективне нормативно-правове забезпечення подолання мобінгу; дано рекомендації органам державної влади та органам місиевого самоврядування щодо можливих шляхів не лише покарання за мобінг, а насамперед його запобігання 6 установах, організаціях та на підприємствах різних форм власності.

Ключові слова:мобінг (иькування), вертикальний, горизонтальний та інституціональний мобінг, моральне переслідування, психологічне насилля, трудовий колек- 
тив, механізми правового регулювання.

The article considers the theoretical foundations of the existence of such an extremely dangerous social phenomenon as mobbing (harassment) at work (both vertical and horizontal); It is shown that in Ukrainian society psychological pressure on employees is growing due to the time of incompetent managers, their personal ambitions (bossing), lack of jobs, the desire of some unscrupulous and incompetent employees undeservedly to take a more promising and better paid job, permanent unemployment growth., which is currently complicated by the COVID-19 epidemic; the history of studying and describing mobbing is studied; It is proved that, in addition to vertical and horizontal mobbing, in our reality there is also institutional mobbing, by which scientists understand the moral persecution of employees, including in the public service, using such institutions as competitions, annual evaluation, staff certification, qualification examinations, consideration of official disputes, official investigations, etc .; covered international and European legislation to prevent and combat mobbing; it is shown that the tendencies of the Ukrainian legislative process show that the Ukrainian state tries to consistently pursue a policy of ensuring the right to respect for the honor and dignity of the individual; at the same time, it has been proved that the issue of combating mobbing has not been properly enshrined in domestic legislation; the perspective normative-legal maintenance of overcoming of mobbing is analyzed; recommendations were given to public authorities and local governments on possible ways not only to punish mobbing, but first of all to prevent it in institutions, organizations and enterprises of various forms of ownership.

Keywords:mobbing, vertical, horizontal and institutional mobbing, moral persecution, psychological violence, labor collective, mechanisms of legal regulation.

Постановка проблеми. Тенденції українського законотворчого процесу свідчать: держава намагається послідовно проводити політику із забезпечення конституційного права на повагу до честі й гідності особи. Ще в січні 2019 року набрав чинності Закон «Про внесення змін до деяких законодавчих актів України щодо протидії булінгу» [15]. Його положення реалізуються на практиці - і кривдників уже притягають до адміністративної відповідальності (детально про булінг можна прочитати в нашій статті [8]). Наступним логічним кроком стало розроблення регламентації протидії мобінгу - цькуванню в трудових правовідносинах. Відповідні проєктизаконів України було зареєстровано у Верховній Раді VIIІскликання «Про внесення змін до деяких законів України (щодо запобігання мобінгу) (проєкт Закону України від 25 липня 2017 року №7005, внесений народними депутатами України VIII скликання Д. Лінько та А. Лозовим) [14] та «Про внесення змін до деяких законодавчих актів України щодо протидії мобінгу (проєкт Закону України від 01 березня 2019 року №10118, внесений народними депутатами України VIII скликання Білозір О. В., Співаковський О. В.) [13] та ін. Водночас парламентарі VIIІкликання так і не спромоглися ухвалити відповідний законопроєкт щодо протидії мобінгу. Наразі у Верховній Раді України зареєстровано новий законопроєкт від 02 листопада 
2020 року за № 4306 «Про внесення змін до Кодексу України про адміністративні правопорушення щодо протидії мобінгу», внесений народними депутатами України Ю.М. Гришиною та ін. [16]. Зважаючи на монолітність парламентської більшості, будемо сподіватися, що парламентарі IX скликання зрештою спроможуться ухвалити відповідних законопроєкт щодо запобігання та протидії цькуванню на роботі.

Аналіз останніх досліджень і публікацій. Останнім часом (упродовж 2018-2019 рр.) до проблеми цькування в колективі (мобінгу, босингу, харасменту, булінгу) у своїх наукових розвідках зверталися Карпенко 3.С. (досліджено мобінг в акмеперіоді: ризики і ресурси корекції життєвого сценарію особистості, 2018) [3], Корабльова О.О. (описано профілактику мобінгу в шкільному середовищі у контексті діяльності UNICEF в Україні, 2018) [6], Марисюк К. (досліджено поняття, суть та питання криміналізації мобінгу, 2018) [9], Смук О.Т. (показано мобінг як наслідок злоякісної агресії, 2018) [19], Червінська Л.П. (досліджено мобінг персоналу як соціальне явище організації, 2018) [22], Щетініна Л.В., Рудакова С.Г., Дробинська К. О. (Мобінг: сутність та інституційні засади захисту працівників, 2018) [24], Лопушинський І.П., Ковнір O.I. (вивчено механізми попередження булінгу (цькування) серед учасників освітнього процесу) [8], Колєснік Т.В. (показано сучасні підходи до запобігання мобінгу у трудових відносинах, 2019) [4] та ін. До проблем мобінгу в органах державної влади зверталися в своїй статті Конотопцева В.О. та Євдокимов Ю.В. ще 2012 року («Шляхи подолання мобінгу в управлінні персоналом державної служби») [5] та Філіппова В.Д. і Філіппова В.В. («Мобінг і харасмент як детермінанти міжособистісних відносин у структурах державного органу», 2019) [20].

Водночас у їхніх та інших наукових розвідкахпо суті не було проаналізовано останні законопроєкти щодо подолання цього негативного явища в трудових колективах та не показано перспектив покарання за вчинення мобінгу. Щодо аналізу законодавчих перспектив урегулювання проблеми мобінгу нам відома лише одна стаття Костюк Н.П. та Скубченко Д.О., де було проаналізовано тогочасні перспективи запровадження механізмів правового регулювання мобінгу в Україні, 2019) [7].

Мета статті. Саме тому метою нашої статті й став аналіз останнього законопроєкту щодо протидії мобінгу (цькування)[16], щопокликаний привести норми українського законодавства відповідно до європейського законодавства та забезпечити захист від дискримінації й психологічного тиску в трудовому колективі.

Виклад основного матеріалу. Як відомо, Конституцією України передбачається право кожного громадянина на повагу його честі й гідності, право на працю та відповідні й безпечні умови праці, водночас трудовим законодавством не визначено механізму їх захисту. Нині в умовах затяжної соціальної та економічної кризи, зростання рівня безробіття (відповідно до показників, розміщених на офіційному сайті Державної служби статистики, станом на 1 липня 2020 104 
року рівень безробіття в Україні складав 9,1\%, або на 1,1\% більше від аналогічного періоду 2019 року) [11] у суспільстві зростає психологічний пресинг на працівників, ускладнений наразі ще й епідемією COVID-19. Таким чином, реалізація гарантованих Конституцією прав на забезпечення гідних умов праці стикається з проблемою психологічного тиску на робочих місцях, тобто мобінгу.

Як відомо, мо́бінг (цькування, від англ. tomob - нападати, труїти)- систематичне цькування, психологічний терор, форми зниження авторитету, форма психологічного тиску у вигляді цькування співробітника в колективі, зазвичай 3 метою його звільнення.

Традиційно виокремлюють два види мобінгу: 1) вертикальний - «босинг» (від анг. boss - хазяїн, шеф), коли психологічний терор стосовно працівника виходить від начальника. Босинг скеровано на одного із працівників, він супроводжується створенням угруповань в організації, залученням до психологічного тиску на працівника й інших членів організації; 2) горизонтальний - коли психологічний терор виходить від колег. В англосаксонському діалекті це поняття позначають як булінг (від анг. bullying - знущатися). Вітчизняна практика свідчить, що, крім вертикального і горизонтального мобінгу, у наших реаліях має місце й інституціональний мобінг, під яким науковці розуміють моральне переслідування працівників, у тому числі й на публічній службі, з використанням таких інститутів, як щорічна оцінка, атестація персоналу, кваліфікаційні іспити, розгляд службових спорів, службові розслідування тощо.

Поняття мобінг було запроваджено ще на початку 80 -х років XX століття Ганцом Лейманом (психолог, медик-науковець), яким було проведено дослідження «Мобінг як явище на робочих місцях у Швеції на початку 1980-х» та надано визначення терміна: «Мобінг - психологічне насилля, систематично повторюване вороже і неетичне ставлення однісї або кількох осіб, скероване проти іншої особи» [12].

Згодом, спираючись на дослідження науковців, Міжнародною організацією праці (МОП) було надано таке визначення терміна: «Під психологічним насиллям на робочому місці розуміється образливе, мстиве, жорстоке, злостиве або принизливе поводження 3 окремою особою або групою працівників, що охоплює колективний пресинг або мобінг проти обраного працівника, який стає об'єктом психічного тиску. Мобінг передбачає постійну негативну увагу або критику, ізоляцію особи від суспільних контактів, поширення неправдивої інформації» [23].

Мобінг провокує звільнення з роботи, судові процеси, неврози, суїциди і матеріальні втрати. Це явище характерне як для державних установ, так і для приватних фірм. На робочому місці віднього страждають чоловіки і жінки, досвідчені професіонали і молоді працівники. Було встановлено, що в деяких країнах, де рівень безробіття сягає критичної відмітки (сюди можна додати й Україну - авт.), від мобінгу страждає до 17\% співробітників окремих фірм. Мобінг шкодить не лише співробітнику-жертві, а й фірмі, тому що гальмує ро- 
бочий процес. За статистикою, у країнах Західної Свропи мобінгу зазнають майже $20 \%$ працівників. Водночас статистикаопирається тільки на точні дані, отже, існує ризик, що ця цифра насправді більша, оскільки багато працівниківз цього приводу мовчать або просто полишають місце роботи, не називаючи справжньої причини.

Сьогодні в більшості зарубіжних країн знають, що таке мобінг, і на законодавчому рівні регулюється протидія цьому явищу. Тут слід виокремити Європейську соціальну хартію від 18 жовтня 1961 року, якою було визначено обов'язок держави сприяти припиненню агресивних і принижувальних дій проти працівників на робочих місцях та вживати необхідних заходів щодо їхнього захисту від дискримінаційних дій з боку роботодавця [1]; Директиву Європейського Союзу № 89/391/ЄС від 12 червня 1989 року «Про запровадження заходів, покликаних заохочувати до поліпшення безпеки та охорони здоров'я працівників на роботі» [18].

Крім того, відповідно до статті 26 Європейської соціальної хартії(переглянутої) від 3 травня 1996 року [2], ратифікованою Верховною Радою України 14 вересня 2006 року, держави взяли на себе зобов'язання сприяти запобіганню систематичним непорядним або явно негативним та образливим діям щодо окремих працівників на робочому місці або у зв'язку з виконанням роботи і вживати всіх відповідних заходів для захисту працівників від такої поведінки роботодавців [2].

Слід також назвати Директиву Свропейського Союзу від 27 листопада 2000 року № 2000/78/ЄС «Про встановлення загальних правил рівного ставлення у сфері зайнятості та професійної діяльності», що закріплює рівність поводження у сфері праці та зайнятості, визначаючи поведінку з метою створення ворожої, принижуючої гідність людини або образливої обстановки як переслідування працівника, що прирівнюється до дискримінації трудових прав [17]; Хартію основних правСвропейського Союзу від 07 грудня 2000 року, де закріплено недоторканість людської гідності та гарантовано людині право на власну фізичну та психічну цінність [21].

Таким чином, як видно 3 наведеного нами огляду міжнародного та зарубіжного законодавства, питання протидії ознакам мобінгу на робочому місці в світі загалом, та в європейських країнах зокрема врегульоване на законодавчому рівні вже давно. На законодавчому рівні (трудове законодавство) заборону мобінгу та його проявів запроваджено в Данії, Великій Британії, Італії, Квебеку (Канада), Німеччині, Норвегії, Польщі, США, Франції, Швеції (21 березня 1993 року тут навіть було ухвалено окремий закон, скерований на боротьбу з мобінгом на робочому місці), у деяких країнах мобінг розглядається як прояв дискримінації або як прояв психологічного насилля.

Таким чином, мобінг трактується як одна із форм дискримінації прав людини в трудових відносинах, що проявляється через психологічне, економічне та інше насильство з метою приниження людської гідності підлеглих та найманих працівників з боку керівництва за певними ознаками, створення стосовно 106 
них напруженої, ворожої, образливої атмосфери та примушування учасника трудових відносин до зміни місця роботи. Тобто, явище «мобінг»є однією із форм дискримінації прав людини і пов'язане саме з трудовими відносинами.

Оскільки в Україні поняття мобінг з'явилося порівняно нещодавно, на законодавчому рівні питання протидії та заборони мобінгу залишається, як уже зазначалося вище,досі не врегульованим, попри те, що впродовж 2017-2020 років у Верховній Раді України було зареєстровано принаймні три проєкти Закону з названої проблематики $[13 ; 14 ; 16]$.

Як визначали автори проєкту Закону України [13], мобінг (цькування), тобто діяння учасників трудових відносин, які полягають у психологічному, фізичному, економічному насильстві, у тому числі із застосуванням засобів електронних комунікацій, що вчиняються стосовно працівника підприємства, установи, організації незалежно від форми власності, виду діяльності і галузевої належності, а також осіб, які працюють за трудовим договором з фізичними особами або такою особою стосовно інших учасників трудових відносин з метою приниження їх людської гідності за певними ознаками, створення стосовно них напруженої, ворожої, образливої атмосфери та примушування учасника трудових відносин до зміни місця роботи [13].

Народні депутати України IX скликання - автори законопроєкту від 02 листопада 2020 року подають по суті аналогічне визначення мобінгу, що пропонується ввести до Кодексу України про адміністративні правопорушення, доповнивши його статтею 173-5 «Мобінг (цькування), тобто діяння учасників трудових відносин, які полягають у психологічному, економічному насильстві, у тому числі із застосуванням засобів електронних комунікацій, що вчиняються стосовно працівника підприємства, установи, організації незалежно від форми власності, виду діяльності і галузевої належності, а також стосовно осіб, які працюють за трудовим договором 3 фізичними особами або особами, які працюють за трудовим договором $з$ фізичними особами стосовно інших учасників трудових відносин з метою приниження їх людської гідності за певними ознаками, створення стосовно них напруженої, ворожої, образливої атмосфери та/або примушування учасника трудових відносин до зміни місця роботи [16].

Цим же проєктом передбачено покарання за вчинення акту мобінгу накладення штрафу від ста до ста п'ятдесяти неоподатковуваних мінімумів доходів громадян (наразі - 1700 - 2550 грн - aвm.) або громадські роботи на строк від двадцяти до сорока годин. Законопроєкт також закріплює, що «діяння, передбачене частиною першою цієї статті, вчинене групою осіб або повторно протягом року після накладення адміністративного стягнення,тягне за собою накладення штрафу від двохсот до трьохсот неоподатковуваних мінімумів доходів громадян (наразі $3400-5100$ грн - aвm.) або громадські роботи на строк від сорока до шістдесяти годин.Ті самі дії, що спричинили заподіяння шкоди психічному здоров'ю учаснику трудових відносин, тягнуть за собою накладення штрафу від двохсот до трьохсот неоподатковуваних мінімумів доходів громадян (наразі 3400 - 5100 грн - авт.) або громадські роботи на строк від сорока 
до шістдесяти годин [16].

У Законі України «Про засади запобігання та протидії дискримінації в Україні» (Відомості Верховної Ради (ВВР), 2013, № 32, ст.412 із наступними змінами) автори законопроєкту [16] пропонують такі зміни: 1.1) У статті 1 частину першу доповнити новим пунктом «8)» такого змісту: «8) мобінг (цькування), тобто діяння учасників трудових відносин, які полягають у психологічному та/або, економічному насильстві, у тому числі із застосуванням засобів електронних комунікацій, що вчиняються стосовно працівника (працівників) підприємства, установи, організації незалежно від форми власності, виду діяльності і галузевої належності, а також стосовно осіб, які працюють за трудовим договором $з$ фізичними особами або особами, які працюють за трудовим договором 3 фізичними особами стосовно інших учасників трудових відносин 3 метою приниження їх людської гідності за певними ознаками, створення стосовно них напруженої, ворожої, образливої атмосфери та/або примушування учасника трудових відносин до зміни місця роботи [16].

Типовими ознаками мобінгу (цькування), на думку законодавців, [16] є: систематичність (повторюваність) діяння; наявність сторін - кривдник, потерпілий (жертва мобінгу), спостерігачі (у разі наявності);дії або бездіяльність кривдника, наслідком яких є заподіяння психічної шкоди, приниження, страх, тривога, підпорядкування потерпілого інтересам кривдника, та/або спричинення соціальної ізоляції потерпілого, примушування до зміни місця роботи [16].

Як уважають автори законопроєкту [16], економічний тиск - це нерівна оплата за працю рівної цінності, нерівномірний розподіл навантаження і завдань між працівниками, що виконують однакову роботу, позбавлення працівника роботи без його звільнення, нерівність можливостей для кар'єрного зростання, безпідставний недопуск працівника на робоче місце, безпідставне позбавлення частини виплат (премій, бонусів тощо).

На думку законодавців [16], психологічний тиск - це створення ворожої, образливої атмосфери, погрози, висміювання, наклепи. Він може проявлятися, зокрема, у використанні зневажливих зауважень та епітетів, словесній чи невербальній поведінці загрозливого, залякувального або принизливого характеру, саботажі чи підриві робочої діяльності працівника [16].

Створення нестерпного робочого середовища, як гадають законотворці [16], - це ізоляція працівника від трудового колективу, включаючи зміну місцезнаходження робочого місця, не запрошення на зустрічі і наради, у яких працівник зазвичай має брати участь, перенесення робочого місця в непристосовані для цього виду роботи місця, застосування інших формально нейтральних процедур для виведення працівника з психологічної рівноваги, негативного виокремлення працівника 3 колективу, утруднення виконання ним своєї трудової функції. Результатом створення нестерпного робочого середовища може бути припинення роботи, зниження кваліфікації, позбавлення перспектив кар'єрного зростання, відсутність або зменшення заохочення, зменшення винагороди за працю.

108 
Цькування, як уважають Ю.М. Гришина та ін. автори проєкту Закону [16] - це приниження гідності працівника, умисні штовхання, пирхання, стусани, удари, нанесення побоїв, тілесних ушкоджень [16].

2) У Кодексі законів про працю України (Відомості Верховної Ради (ВВР), 1971, додаток до № 50, ст. 375 із наступними змінами) автори законопроєкту [16] пропонують зробити такі зміни: 2.1) у статті 2-1 назву статті викласти у такій редакції: «Стаття 2-1. Рівність та захист трудових прав громадян України»; частину першу після слів «або надання підтримки іншим працівникам у захисті їх прав, за мовними або іншими ознаками, не пов'язаними з характером роботи або умовами іiі виконання» доповнити словами «також утиск (мобінг) працівників»; 2.2) у статті 5-1 Абзац сьомий частини першої викласти в такій редакції: «правовий захист від необгрунтованої відмови у прийнятті на роботу, незаконного звільнення, утиску (мобінгу) працівників, сприяння у збереженні роботи, також захисту власної гідності під час здійснення трудової діяльності»; 2.3) У статті 13 частини другої, після абзацу дванадцятого, доповнити новим абзацом такого змісту:«заходи, спрямовані на запобігання та протидію мобінгу (цькуванню) на підприємствах, установах, організаціях та здійснення контролю за заходами протидії мобінгу»; 2.4) частину третю статті 38 після слів «не виконує законодавство про працю, умови колективного чи трудового договору» доповнити словами «здійснював утиск (мобінг) працівника чи не вжив заходів щодо його запобігання»; 2.5) частину першу статті 41 доповнити новим пунктом 1-2) такого змісту: «1-2) вчинення винних дій керівником підприємства, установи, організації із застосуванням мобінгу тобто створення напруженої, образливої атмосфери в колективі, психологічному, економічному насильстві по відношенню до окремих працівників, незалежно від форм прояву»; 2.6) частину першу статті 44 після слів «внаслідок порушення власником або уповноваженим ним органом законодавства про працю, колективного чи трудового договору» доповнити словами «утиску (мобінгу)»; 2.7) частину першу статті 141 після слів «створювати умови для зростання продуктивності праці, забезпечувати трудову і виробничу дисципліну» доповнити словами «протидіяти утиску (мобінгу) працівників»; 2.8) статтю 158 доповнити новою частиною другою такого змісту: «Роботодавець зобов'язаний здійснювати профілактику ризиків та напруги на робочому місці, провадити інформаційні, навчальні та організаційні заходи щодо упередженого ставлення у сфері праці (мобінг)»;2.9) статтю 173 доповнити новою частиною другою такого змісту: «У разі ушкодження здоров'я працівника, причиною якого став утиск (мобінг), заподіяна шкода відшкодовується в розмірі понесених витрат на лікування»;2.10) частину першу статті 237-1 після слів «відшкодування власником або уповноваженим ним органом моральної шкоди працівнику провадиться у разі, якщо порушення його законних прав» доповнити словами «у тому числі внаслідок дискримінації, утиску (мобінгу)» [16].

У Законі України «Про колективні договори і угоди» (Відомості Верховної Ради України (ВВР), 1993, № 36, ст.361 із наступними змінами) автори за- 
конопроєкту [16] пропонують закріпити такі зміни: 3.1) У статті 7 частини другої, після абзацу дванадцятого, доповнити новим абзацом такого змісту:«заходи, спрямовані на запобігання та протидію мобінгу (цькуванню) на підприємствах, установах, організаціях та здійснення контролю за заходами протидії мобінгу»; 3.2) У статті 8 частини першої, після абзацу десятого, доповнити новим абзацом такого змісту:«заходи, спрямовані на запобігання та протидію мобінгу (цькуванню) на підприємствах, установах, організаціях та здійснення контролю за заходами протидії мобінгу»; 3.3) У статті 8 частини другої, після абзацу дев'ятого, доповнити новим абзацом такого змісту:«заходи, спрямовані на запобігання та протидію мобінгу (цькуванню) на підприємствах, в установах, організаціях та здійснення контролю за заходами протидії мобінгу» [16].

Як нам видається, ухвалення цього законопроєкту сприятиме суттєвому поліпшенню ситуації із запобіганням та протидією в нашій країні мобінгу, він слугуватиме покажчиком руху до мінімізації цього ганебного явища у вітчизняних реаліях. Водночас, лише ухваленням закону та напрацюванням підзаконних нормативно-правових актів, покаранням за скоєння мобінгу цю справу не вирішити. Органи публічного управління (державна влада і місцеве самоврядування) мають зосередити свою увагу на якнайскорішому зменшенні до мінімуму безробіття в країні, створенні нових високотехнологічних робочих місць, належному навчанні персоналу, налагодженні європейського штибу HRменеджменту в умовах, коли багато хто хоче поміняти професію на більш високооплачувану спеціальність, а роботодавці з особливою ретельністю відносяться до добору кваліфікованого персоналу, виховання і розстановки на керівні посади неформальних лідерів, які мають здійснювати вплив на працівників, використовуючи власні здібності й уміння, а також наявні в них ресурси, що потрібні людям, при цьому ще й відмовившись від т. зв. «кумівства», формування належної корпоративної культури, тобто системи цінностей та переконань, що розділяє кожен працівник фірми та передбачає його поведінку, зумовлює характер життєдіяльності організації та відповідного морально-психологічного клімату в трудових колективах, тобтотаке, щопереважає в групі або колективі відносно стійке психологічне налаштування його членів, якевиявляється в різноманітних формах їхньої діяльності.

Висновки. 1. У літературі мобінг визначається як психологічний терор, переважно груповий, цькування щодо будь-кого 3 працівників з боку його колег, підлеглих або керівництва, що включають в себе постійні негативні висловлювання на адресу працівника, його соціальну ізоляцію всередині організації, поширення про працівника завідомо неправдивої інформації. 2. Традиційно виокремлюють два види мобінгу - вертикальний (цькування працівника керівником) і горизонтальний (переслідування колегами). Водночас вітчизняна практика свідчить, що, крім вертикального і горизонтального мобінгу, у наших реаліях має місце й інституціональний мобінг, під яким науковці розуміють моральне переслідування працівників, у тому числі й на публічній 110 
службі, з використанням таких інститутів, як щорічна оцінка, атестація персоналу, кваліфікаційні іспити, розгляд службових спорів, службові розслідування тощо. 3. Сьогодні в більшості зарубіжних країн знають, що таке мобінг, і на законодавчому рівні регулюється протидія цьому явищу. Водночас в українському законодавстві та нормативно-правових актахпитання протидії мобінгу ще не знайшло свого належного закріплення. 4. У цьому зв'язкунами проаналізовано перспективне нормативно-правове забезпечення подолання мобінгу, насампередпроєкт Закону України від 02 листопада 2020 року № 4306 «Про внесення змін до Кодексу України про адміністративні правопорушення щодо протидії мобінгу, внесений народними депутатами України Ю.М. Гришиною та ін. 5. Дано рекомендації органам державної влади та органам місцевого самоврядування щодо можливих шляхів не лише покарання за мобінг, а насамперед його запобігання в установах, організаціях та на підприємствах різних форм власності, насамперед щодо подолання безробіття через створення нових робочих місць, належної організації роботи служб персоналу (HR-менеджменту), виховання неформальних лідерів, формування в колективах корпоративної культури, забезпечення належного морально-психологічного клімату тощо.

Подальші дослідження порушеної нами в статті проблеми стосуватимуться аналізові перших кроків виконання законопроєкту від 02 листопада 2020 року № 4306 [16] після можливого його ухвалення як Закону Верховною Радою України.

\section{Список використаних джерел:}

1. Свропейська соціальна хартія від 18 жовтня 1961 року. URL: https://zakon.rada.gov.ua/laws/show/994_300\#Text.

2. Свропейська соціальна хартія (переглянута). URL:https://zakon.rada.gov.ua/laws/show/994_062\#Text.

3. Карпенко 3.С. Мобінг в акмеперіоді: ризики і ресурси корекції життєвого сценарію особистості // Психологічний часопис. 2018. № 6. С. 82-94. Режим доступу: http://nbuv.gov.ua/UJRN/psch_2018_6_8.

4. Колєснік Т.В. Сучасні підходи до запобігання мобінгу у трудових відносинах // Правовий часопис Донбасу. 2019. № 3. С. 65-72. Режим доступу: http://nbuv.gov.ua/UJRN/pppd_2019_3_10.

5. Конотопцева В.О., Свдокимов Ю.В. Шляхи подолання мобінгу в управлінні персоналом державної служби // Актуальні проблеми державного управління. 2012. № 2. С. 331-337. Режим доступу: http://nbuv.gov.ua/UJRN/apdy_2012_2_47.

6. Корабльова О.О. Профілактика мобінгу в шкільному середовищі у контексті діяльності UNICEF в Україні // Збірник наукових праць Хмельницького інституту соціальних технологій Університету "Україна". 2018. №1. С. 130-132. Режим доступу: http://nbuv.gov.ua/UJRN/Znpkhist_2018_1_32.

7. Костюк Н.П., Скубченко Д. О. Перспективи запровадження механізмів правового регулювання мобінгу в Україні // Аспекти публічного управління. 2019. T. 7, № 9-10. С. 19-31. Режим доступу: http://nbuv.gov.ua/UJRN/aplup_2019_7_9-10_4. 
8. Лопушинський І.П., Ковнір О.І. Механізми попередження булінгу (цькування) серед учасників освітнього процесу // Державне управління у сфері цивільного захисту: наука, освіта, практика: матеріали Міжнародної науковопрактичної конференції, 17-18 травня 2019 р. / за заг. ред. В.П. Садкового. Х.: Вид-во НУЦЗУ, 2019. С. 36-39.

9. Марисюк К. Мобінг: поняття, суть та питання криміналізації // Вісник Національного університету "Львівська політехніка". Юридичні науки. 2018. Вип. 17. C. 132-136. Режим доступу: http://nbuv.gov.ua/UJRN/vnulpurn_2018_17_22.

10. Новіков, Денис. Мобінг поза законом: як протидіяти насильству на роботі. Режим доступу: https://commons.com.ua/uk/mobing-poza-zakonom-yakprotidiyati-nasilstvu-na-roboti/.

11. Офіційний сайт Державної служби статистики України. URL: www.ukrstat.gov.ua.

12. Проблеми мобінгу в Україні обговорено під час круглого столу у Комітеті $з$ питань соціальної політики, зайнятості та пенсійного забезпечення Верховної Ради України. URL: https://iportal.rada.gov.ua/print/170939.html.

13. Про внесення змін до деяких законодавчих актів України щодо протидії мобінгу: проєкт Закону України від 01 березня 2019 року №10118, внесений народними депутатами України VIII скликання Білозір О. В., Співаковським О. В. та ін. Режим доступу: http://search.ligazakon.ua/1_doc2.nsf/link1/JH7T200A.html.

14. Про внесення змін до деяких законів України (щодо запобігання мобінгу): проєкт Закону України від 25 липня 2017 року №7005, внесений народними депутатами України VIIIскликання Д. Лінько та А. Лозовим. Режим доступу: http://search.ligazakon.ua/__doc2.nsf/link1/JH5EL00I.html.

15. Про внесення змін до деяких законодавчих актів України щодо протидії булінгу: Закон України від 18 грудня 2018 року № 2657-VIII. URL: https://zakon.rada.gov.ua/laws/show/2657-19\#Text.

16. Про внесення змін до Кодексу України про адміністративні правопорушення щодо протидії мобінгу: проєкт Закону України, внесений народними депутатами України Ю.М.Гришиною та ін., зареєстрований у Верховній Раді України 02 листопада 2020 року за № 4306. URL: http://w1.c1.rada.gov.ua/pls/zweb2/webproc4_1?id=\&pf3511=70300.

17. Про встановлення загальних правил рівного ставлення у сфері зайнятості та професійної діяльності: Директива від 27 листопада 2000 року № 2000/78/EC. URL: https://www.rac.org.ua/uploads/content/305/files/directive2000-78.pdf.

18. Про запровадження заходів, покликаних заохочувати до поліпшення безпеки та охорони здоров'я працівників на роботі: Директива Європейського Союзу від 12 червня 1989 року № 89/391/EC.URL: https://zakon.rada.gov.ua/laws/show/994_b23\#Text.

19. Смук О.Т. Мобінг як наслідок злоякісної агресії // Науковий вісник Ужгородського національного університету. Серія : Педагогіка. Соціальна робота. 2018. Вип. 2. С. 260-264. URL: http://nbuv.gov.ua/UJRN/Nvuuped_2018_2_52.

20. Філіппова В.Д., Філіппова В. В. Мобінг і харасмент як детермінанти міжособистісних відносин у структурах державного органу // Теорія та практика державного управління і місцевого самоврядування. 2019. № 1. Режим доступу: 
http://nbuv.gov.ua/UJRN/Ttpdu_2019_1_36.

21. Хартія основних прав Свропейського Союзу від 07 грудня 2000 року. URL: https://zakon.rada.gov.ua/laws/show/994_524\#Text.

22. Червінська Л.П. Мобінг персоналу як соціальне явище організації // Соціально-трудові відносини: теорія та практика. 2018. № 1. С. 130-136. Режим доступу: http://nbuv.gov.ua/UJRN/stvttp_2018_1_14.

23. Шамшиева А.В., Юричка Ю.И. Моббингкак форма проявлениямежличностногоконфликта в организации // Психологопедагогическиепроблемыличности и общества: м-лымежд. научно-практ. конф. (20.02.2014 года). Днепропетровск, 2014, С. 112-114.

24. Щетініна Л.В., Рудакова С. Г., Дробинська К. О. Мобінг: сутність та інституційні засади захисту працівників // Проблеми економіки. 2018. № 1. С. 315 320. Режим доступу: http://nbuv.gov.ua/UJRN/Pekon_2018_1_43.

\section{References:}

1. Yevropeyska sotsial nakhartiya vid 18 zhovtnya 1961 roku [European Social Charter of 18 October 1961]. Retrieved from https://zakon.rada.gov.ua/laws/show/994_300\#Text [in Ukrainian].

2. Yevropeyska sotsial nakhartiya (perehlyanuta) [European Social Charter (revised)]. Retrieved fromhttps://zakon.rada.gov.ua/laws/show/994_062\#Text [in Ukrainian].

3. Karpenko Z. S. (2018) Mobinh v akmeperiodi: ryzyky i resursy korektsiyi zhyttyevoho stsenariyu osobystosti [Mobbing in the acme period: risks and resources of correction of the life scenario of the individual] Psykholohichnyy chasopys - Psychological Journal, 6, 82-94. Retrieved from http://nbuv.gov.ua/UJRN/psch_2018_6_8 [in Ukrainian].

4. Kolyesnik T. V. (2019) Suchasnipidkhody do zapobihannya mobinhu u trudovykh vidnosynakh [Modern approaches to preventing mobbing in labor relations] PravovyychasopysDonbasu - Legal Journal of Donbass, 3, 65-72. Retrieved fromhttp://nbuv.gov.ua/UJRN/pppd_2019_3_10 [in Ukrainian].

5. Konotoptseva V. O., Yevdokymov YU. V. (2012) Shlyakhypodolannya mobinhu v upravlinni personalom derzhavnoyi sluzhby [Ways to overcome mobbing in the management of personnel of the civil service] Aktual niproblemy derzhavnohoupravlinnya - Actual problems of public administration, 2, 331-337. Retrieved fromhttp://nbuv.gov.ua/UJRN/apdy_2012_2_47 [in Ukrainian].

6. Korablova O. O. (2018) Profilaktyka mobinhu v shkil nomuseredovyshchi u konteksti diyalnosti UNICEF v Ukrayini [Prevention of mobbing in the school environment in the context of UNICEF in Ukraine] Zbirnyknaukovykh prats Khmelnytskoho instytutu sotsial nykhtekhnolohiy Universytetu "Ukrayina" - Collection of scientific works of the Khmelnytsky Institute of Social Technologies of the University "Ukraine", 1, 130-132. Retrieved from http://nbuv.gov.ua/UJRN/Znpkhist_2018_1_32 [in Ukrainian].

7. Kostyuk N. P. (2019) Perspektyvy zaprovadzhennya mekhanizmiv pravovoho rehulyuvannya mobinhu v Ukrayini [Perspectives of introduction of mechanisms of legal regulation of mobbing in Ukraine] $N$. P. Kostyuk, D. O. Skubchenko.Aspektypublichnohoupravlinnya - Aspects of public administration, T. 7, 9-10, 19-31. Retrieved from http://nbuv.gov.ua/UJRN/aplup_2019_7_9-10_4 [in Ukrainian].

8. Lopushynskyy I. P., Kovnir O. I. (2019) Mekhanizmy poperedzhennya bulinhu (tskuvannya) sered uchasnykiv osvitnoho protsesu [Mechanisms for preventing bullying 
(harassment) among participants in the educational process]Derzhavneupravlinnya $u$ sferitsyvil nohozakhystu: nauka, osvita, praktyka: materialyMizhnarodnoyinaukovopraktychnoyikonferentsiyi, 17-18 travnya 2019 r. / zazah. red. V. P. Sadkovoho - Public administration in the field of civil defense: science, education, practice: materials of the International scientific-practical conference, May 17-18, 2019 p. / зазаг. ed. VP Sadkov, KH.: Vyd-vo NUTSZU, 2019, 36-39 [in Ukrainian].

9. Marysyuk K. (2018)Mobinh: ponyattya, sut ta pytannyakryminalizatsiyi [Mobbing: concept, essence and issues of criminalization] Visnyk Natsionalnoho universytetu "Lvivska politekhnika". Yurydychninauky - Bulletin of the National University "Lviv Polytechnic". Legal sciences, 17, 132-136.Retrieved from http://nbuv.gov.ua/UJRN/vnulpurn_2018_17_22 [in Ukrainian].

10. Novikov, Denys. Mobinh poza zakonom: yak protydiyaty nasylstvu na roboti [Mobbing outside the law: how to counteract violence at work]. Retrieved fromhttps://commons.com.ua/uk/mobing-poza-zakonom-yak-protidiyati-nasilstvu-na-roboti/ [in Ukrainian].

11. Ofitsiynyysayt Derzhavnoyi sluzhby statystyky Ukrayiny - Official site of the State Statistics Service of Ukraine.Retrieved from www.ukrstat.gov.ua [in Ukrainian].

12. Problemy mobinhu v Ukrayini obhovoreno pid chas kruhloho stolu u Komiteti z pytan sotsialnoyi polityky, zaynyatosti ta pensiynoho zabezpechennya Verkhovnoyi Rady Ukrayiny [The problems of mobbing in Ukraine were discussed during a round table in the Committee on Social Policy, Employment and Pensions of the Verkhovna Rada of Ukraine]. Retrieved from https://iportal.rada.gov.ua/print/170939.html [in Ukrainian].

13. Pro vnesennya zmin do deyakykh zakonodavchykh aktiv Ukrayiny shchodo protydiyi mobinhu: proyekt Zakonu Ukrayiny vid 01 bereznya 2019 roku №10118, vnesenyynarodnymydeputatamyUkrayiny VIII sklykannyaBilozir O. V., Spivakovskym O. V. ta in. [On amendments to some legislative acts of Ukraine on combating mobbing: the draft Law of Ukraine of March 1, 2019 №10118, introduced by the People's Deputies of Ukraine of the VIII convocation BilozirOV, Spivakovsky OV and others.]. Retrieved from http://search.ligazakon.ua/1_doc2.nsf/link1/JH7T200A.html [in Ukrainian].

14. Pro vnesennyazmin do deyakykh zakoniv Ukrayiny (shchodo zapobihannya mobinhu): proyekt Zakonu Ukrayiny vid 25 lypnya 2017 roku №7005 [On amendments to some laws of Ukraine (on the prevention of mobbing): the draft Law of Ukraine of July 25, 2017 №7005, introduced by the People's Deputies of Ukraine of the VIII convocation D. Linko and A. Lozov]. from http://search.ligazakon.ua/1_doc2.nsf/link1/JH5EL00I.html [in Ukrainian].

15. Pro vnesennya zmin do deyakykh zakonodavchykh aktiv Ukrayiny shchodo protydiyi bulinhu: Zakon Ukrayiny vid 18 hrudnya 2018 roku № 2657-VIII [On amendments to some legislative acts of Ukraine on combating bullying: Law of Ukraine of December 18, 2018 № 2657-VIII].Retrieved from https://zakon.rada.gov.ua/laws/show/265719\#Text [in Ukrainian].

16. Pro vnesennya zmin do Kodeksu Ukrayiny pro administratyvni pravoporushennya shchodo protydiyi mobinhu: proyekt Zakonu Ukrayiny 02 lystopada 2020 rokuza № 4306 [On Amendments to the Code of Ukraine on Administrative Offenses to Combat Mobbing: Draft Law of Ukraine, submitted by People's Deputies of Ukraine Yu. M. Hryshyna and others, registered in the Verkhovna Rada of Ukraine on November 2, 2020 at № $\quad 4306]$ Retrieved 
fromhttp://w1.c1.rada.gov.ua/pls/zweb2/webproc4_1?id=\&pf3511=70300 [in Ukrainian].

17. Pro vstanovlennya zahalnykh pravyl rivnoho stavlennya u sferi zaynyatosti ta profesiynoyi diyalnosti: Dyrektyva vid 27 lystopada 2000 roku № 2000/78/EC [On the establishment of common rules for equal treatment in employment and occupation: Directive of 27 November 2000 № 2000/78 / EC]. Retrieved from https://www.rac.org.ua/uploads/content/305/files/directive2000-78.pdf [in Ukrainian].

18. Pro zaprovadzhennya zakhodiv, poklykanykh zaokhochuvaty do polipshennya bezpeky ta okhorony zdorovya pratsivnykiv na roboti: Dyrektyva Yevropeyskoho Soyuzu vid 12 chervnya 1989 roku № 89/391/EC [On the introduction of measures to encourage the improvement of the safety and health of workers at work: Directive of the European Union of 12 June 1989 № 89/391 / EC]. Retrieved from https://zakon.rada.gov.ua/laws/show/994_b23\#Text [in Ukrainian].

19. Smuk O. T. (2018) Mobinh yak naslidokzloyakisnoyiahresiyi [Mobbing as a consequence of malignant aggression] Naukovyyvisnyk Uzhhorodskoho natsionalnoho universytetu. Seriya :Pedahohika. Sotsialna robota - Scientific Bulletin of Uzhgorod National University. Series: Pedagogy. Social work,Vyp. 2, 260-264. Retrieved from http://nbuv.gov.ua/UJRN/Nvuuped_2018_2_52 [in Ukrainian].

20. Filippova V. D. (2019) Mobinhikh arasment yak determinant mizhosobystisnykh vidnosyn u struktura khderzhavnoho orhanu [Mobbing and harassment as determinants of interpersonal relations in the structures of the state body] V. D. Filippova, V. V. Filippova. Teoriya ta praktyka derzhavnoho upravlinnya i mistsevoho samovryaduvannya - Theory and practice of public administration and local government, 1. Retrieved from http://nbuv.gov.ua/UJRN/Ttpdu_2019_1_36 [in Ukrainian].

21. Khartiya osnovnykh prav Yevropeyskoho Soyuzu vid 07 hrudnya 2000 roku [Charter of Fundamental Rights of the European Union of 7 December 2000]. Retrieved from https://zakon.rada.gov.ua/laws/show/994_524\#Text [in Ukrainian].

22. Chervinska L. P. (2018) Mobinh personalu yak sotsialne yavyshche orhanizatsiyi [Mobbing of personnel as a social phenomenon of the organization] Sotsialnotrudovividnosyny: teoriyatapraktyka - Socio-labor relations: theory and practice, 1, 130136. Retrieved from http://nbuv.gov.ua/UJRN/stvttp_2018_1_14 [in Ukrainian].

23. Shamshyeva A. V., Yurychka YU. Y. (2014) Mobbynh kak forma proyavlenyya mezhlychnostnoho konflykta $\mathrm{v}$ orhanyzatsyy [Mobbing as a form of manifestation of interpersonal conflict in the organization] Psykholoho-pedahohycheskyeproblemylychnosty y obshchestva: m-lymezhd. nauchno-prakt. konf. (20.02.2014 hoda). Dnepropetrovsk - Psychological and pedagogical problems of personality and society: m-ly int. scientific practice. conf. (February 20, 2014). Dnepropetrovsk, 112-114 [in Ukrainian].

24. Shchetinina L. V. (2018) Mobinh: sutnist ta instytutsiyni zasady zakhystu pratsivnykiv [Mobbing: essence and institutional principles of protection of workers] L. V. Shchetinina, S. H. Rudakova, K. O. Drobynska. Problemy ekonomiky - Problems of economy, 1, 315-320. Retrieved from http://nbuv.gov.ua/UJRN/Pekon_2018_1_43 [in Ukrainian]. 